\title{
CONGENITAL SYPHILIS IN MENTAL DEFEGTIVE ADULTS
}

By

K. C. L. PadDle, Caterham Mental Hospital

ThE relation of congenital syphilis to mental deficiency has for long been the subject of numerous investigations. In 1912 Mott ${ }^{10}$ stated that ' if syphilis can produce arrest of development of the reproductive organs there is surely no reason why it should not lead to arrest of development of the most highly differentiated and specialized tissue of the body, viz., the cerebral cortex, or cause pathological variations in its structure and function.'

Since the introduction of the Wassermann reaction in 1906, an extensive literature dealing with the incidence of positive Wassermann reactions in mental deficiency has made its appearance, unfortunately with widely divergent results.

\section{TABLE I}

Showing Incidence of Positive Wassermann Reactions in the Blood-Serum of Mental Defectives

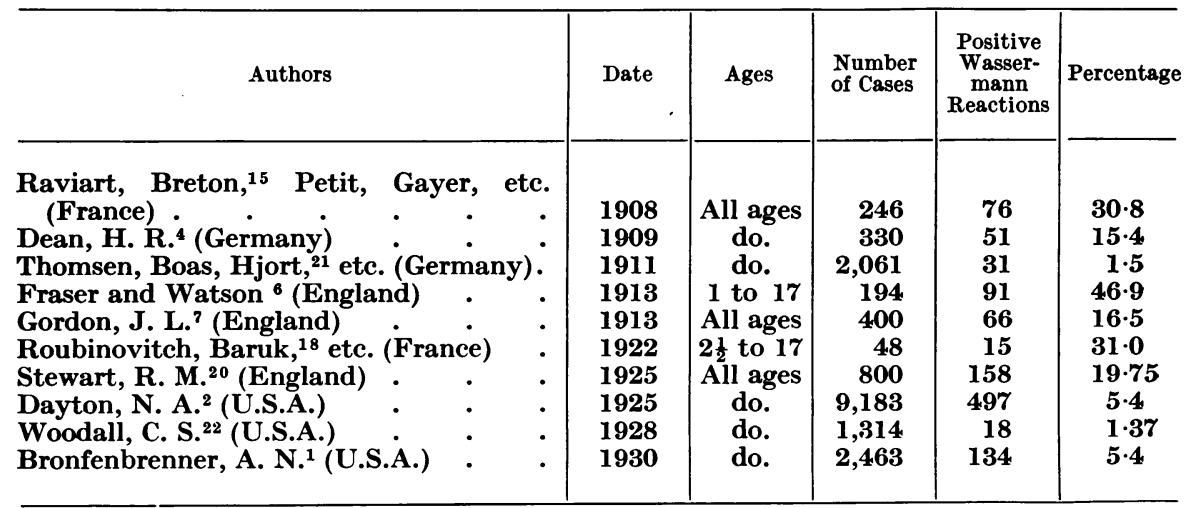

It will be seen that the results vary from 46.9 per cent. to as low as 1.37 per cent. It is probable that the relative sensitivity of the Wassermann reaction in different hands, and the method of interpretation, have had their influence. Kline ${ }^{8}$ mentions the fact that the antigens employed in the majority of precipitation and complement-fixation tests for syphilis contain acetone-soluble adventitious substances ' which not only increase the sensi- 
tivity of results, but also cause false positive reactions, especially when cholesterin in any amount is added.' There are also other factors which influence the incidence of positive Wassermann reactions, such as age, type and grade of defective, and even sex, as will be shown later.

\section{PERSONAL RESEARGHES}

During 1932 and 1933 it was decided to review the whole subject by a thorough investigation into the incidence of congenital syphilis amongst $2,000 *$ mental defectives of both sexes and all grades, inmates of Caterham Mental Hospital.

Bronfenbrenner ${ }^{1}$ has expressed the opinion that 'statistics on the positive Wassermann reaction do not reflect adequately syphilogenic processes and, therefore, cannot be used by themselves for evaluation of syphilis as a factor in the ætiology of feeblemindedness.' Our enquiry has been based on the Wassermann reaction and Meinicke macro clarification reaction (M.K.R.) of the blood serum in all cases, as well as an examination of the cerebrospinal fluid in 1,927 cases, by the Wassermann reaction, cell estimation, globulin and Lange's colloidal gold tests. In addition, clinical examinations of all suspected cases were undertaken, and family histories obtained wherever possible. The tests on the blood and cerebrospinal fluid were carried out at the Central Pathological Laboratory of the London County Mental Hospitals by Dr. S. A. Mann, to whom I am indebted for his unfailing courtesy and kind cooperation in this work. The technique employed is fully described in a memorandum by Mann and Partner. ${ }^{9}$ Briefly, for the Wassermann reaction, the figure following the first plus indicates the number of units of complement ( 1 unit equals approximately 0.01 c.c. of pure guineapig serum) absorbed by 1 c.c. blood-serum or cerebrospinal fluid. The plus following the figure indicates that a further absorption of complement would take place if the range of dilution of serum or cerebrospinal fluid were extended.

For the Meinicke macro clarification test (M.K.R.), four tubes are put up. A positive reaction is indicated by complete clarification of at least one tube.

The method of cell estimation used for the cerebrospinal fluid is only a rough one, 5 c.c. being centrifuged, filmed and stained, and a general expression of the number of cells present given in terms of one to four plus, one plus being equivalent to 15-20 cells per c.mm.; two plus, 20-30 cells ; three plus, 30-40 cells ; and four plus, over 40 cells. The results of the Pandy reaction for excess of globulin in the cerebrospinal fluid are given in terms of one to four plus, according to the density of the cloud produced, when two or three minims of fluid are dropped into a saturated solution of carbolic acid in a test tube at room temperature. 
Among our 2,000 patients were 402 children of 16 years and under, all of whom had both blood and fluid examined. These formed a special group and were separately dealt with in a paper published in the British Journal of Children's Diseases of October, 1933 [Paddle ${ }^{13}$ ], many items of which I am quoting by kind permission of the Editor.

\section{TOTAL NUMBER OF GONGENITAL SYPHILITICS}

The remaining 1,598 adult cases are now reviewed. Of these, 1,492 were found to be serologically negative, and 106 gave various abnormal reactions in their blood-serum, cerebrospinal fluid or both. Excluding 10 cases of acquired syphilis, a full list of results is appended (Tables II-IV).

\section{TABle II}

\section{Congenital Syphilitic Male Defectives}

\begin{tabular}{|c|c|c|c|c|c|c|c|c|c|c|c|c|c|c|}
\hline \multirow{2}{*}{ 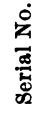 } & \multirow{2}{*}{ 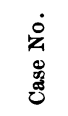 } & \multirow[b]{2}{*}{$\frac{\infty}{4}$} & \multirow{2}{*}{ 莺 } & \multirow{2}{*}{ 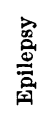 } & \multirow{2}{*}{ 总 } & \multirow{2}{*}{ 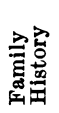 } & \multirow{2}{*}{ 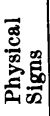 } & \multicolumn{2}{|c|}{ Blood-serum } & \multicolumn{4}{|c|}{ pinal Fluid } & \multirow{2}{*}{ Remarks } \\
\hline & & & & & & & & W.R. & M.K.R. & W.R. & Cells & Pandy & Lange & \\
\hline 1 & 87 & 41 & Imb.L. & + & - & $\mathbf{N} \mathbf{K}$ & & $+30+$ & $1+t+$ & - & - & & & \\
\hline 2 & 138 & $\begin{array}{l}\mathbf{4 1} \\
32\end{array}$ & F.M. & \pm & 二 & N.K. & \pm & $+30+$ & $++t$ & - & 二 & 二 & 二 & \\
\hline 3 & 150 & 18 & Imb.M. & - & - & N.K. & + & $+30+$ & ++++ & - & - & - & - & \\
\hline 4 & 464 & 19 & F.M. & - & - & + & \pm & - & +++ & 一 & 一 & 一 & - & \\
\hline 5 & 1,143 & 17 & Imb.L. & - & - & N.K. & \pm & $\overline{0}$ & ++ & 一 & 一 & 一 & 一 & \\
\hline 6 & 1,205 & 25 & Imb.M. & - & - & N.K. & + & $+30+$ & ++++ & - & - & - & - & \\
\hline 7 & 1,232 & 23 & Imb.L. & + & - & N.K. & + & +15 & ++++ & - & 一 & - & 一 & \\
\hline 8 & 1,239 & 19 & Imb.M. & 1 & - & N.K. & - & - & +++ & - & - & - & 一 & \\
\hline 9 & 1,251 & 24 & Imb.L. & - & + & N.K. & - & $+30+$ & $++t$ & 二 & 二 & 二 & 二 & \\
\hline 10 & 1,261 & 33 & Imb.H. & + & - & N.K. & \pm & +10 & ++++ & - & 一 & 一 & - & \\
\hline 11 & 1,265 & 20 & Imb.L. & - & - & N.K. & $t$ & $+30+$ & ++++ & 一 & - & - & - & Choroiditis \\
\hline 12 & 1,269 & 17 & Imb.L. & - & - & \pm & \pm & - & +++ & 一 & 一 & - & 一 & \\
\hline 13 & 1,278 & 20 & F.M. & - & + & N.K. & \pm & $\overline{1}$ & +++ & - & - & 一 & - & \\
\hline 14 & 1,319 & 18 & Imb.H. & - & + & N.K. & $\mp$ & +15 & +++ & - & - & 一 & - & \\
\hline 15 & 1,346 & 24 & Imb.M. & - & - & N.K. & \pm & 一 & ++ & - & 一 & - & 一 & \\
\hline 16 & 1,360 & 21 & Imb.L. & - & - & + & \pm & $\overline{0}$ & +++ & - & - & - & 一 & \\
\hline 17 & 1,376 & 23 & Imb.M. & + & + & N.K. & + & $+30+$ & ++++ & - & - & - & 一 & \\
\hline 18 & 1,382 & 28 & Imb.L. & + & - & N.K. & \pm & $\overline{1}$ & ++ & 一 & - & - & 一 & \\
\hline 19 & 1,415 & 31 & Imb.L. & + & - & N.K. & \pm & +10 & $+t$ & 一 & - & - & 一 & \\
\hline 20 & 1,424 & 23 & F.M. & + & - & N.K. & $\mp$ & 一 & $++t$ & 一 & 一 & 一 & - & Choroiditis \\
\hline 21 & 1,441 & 23 & Imb.M. & + & - & $\bar{\pi}$ & 一 & 一 & ++ & 一 & - & 一 & - & \\
\hline 22 & 1,504 & 35 & Imb.M. & - & - & N.K. & + & $\overline{0}$ & ++ & 一 & - & - & 一 & \\
\hline 23 & 1,571 & 18 & Imb.L. & - & - & + & + & $+30+$ & ++++ & - & - & - & - & Mongolian \\
\hline 24 & 1,581 & 38 & F.M. & - & - & N.K. & \pm & $\overline{0}$ & ++++ & 一 & - & - & 一 & \\
\hline 25 & 1,618 & 23 & Imb.L. & + & - & + & \pm & $+30+$ & ++++ & - & - & 一 & 一 & \\
\hline 26 & 1,672 & 30 & Imb.H. & - & 一 & + & + & - & & - & - & 一 & - & \\
\hline 27 & 1,714 & 54 & Imb.M. & - & - & N.K. & + & - & $+t$ & - & 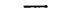 & - & - & \\
\hline 28 & 1,768 & 29 & F.M. & - & - & N.K. & \pm & $+30+$ & $1+++$ & 一 & - & - & - & \\
\hline 29 & 1,813 & 42 & Imb.M. & - & 一 & N.K. & \pm & - & +++ & 一 & 一 & - & 一 & \\
\hline 30 & 1,827 & 60 & Imb.M. & - & - & N.K. & \pm & $+30+$ & +++ & - & - & - & 一 & \\
\hline 31 & 1,845 & 57 & Imb.M. & + & + & N.K. & + & - & +++ & - & - & 二 & 二 & \\
\hline 32 & 1,856 & 64 & Imb.M. & - & - & N.K. & + & $\overline{30}$ & ++ & & & & & \\
\hline 33 & 1,979 & 23 & F.M. & - & - & N.K. & + & +30 & +++ & N.D. & N.D. & N.D. & $\begin{array}{l}\text { N.D. } \\
\text { 5555554321 }\end{array}$ & Juvenile $G, P$ \\
\hline 34 & & 21 & Imb.L. & \pm & \pm & $\mathrm{N}_{\mathrm{K}}^{+}$ & \pm & $+\overline{30}$ & $1++t$ & $+6+$ & $\stackrel{+}{+}$ & $\begin{array}{l}++ \\
+\end{array}$ & 5555554321 & Juvennle G.P \\
\hline 35 & $\begin{array}{r}497 \\
1,151\end{array}$ & $\begin{array}{l}02 \\
17\end{array}$ & $\begin{array}{l}\text { Imb.M. } \\
\text { Imb.L. }\end{array}$ & 二 & $\bar{Z}$ & $\begin{array}{l}\text { N.R. } \\
+\end{array}$ & \pm & 10 & 11 & - & ++ & - & 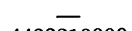 & \\
\hline 37 & 1,250 & 20 & Imb.L. & - & + & N.K. & F & $+30+$ & ++++ & $+15+$ & - & + & 4433210000 & Choroiditis \\
\hline 38 & 1,339 & 26 & Imb.M. & + & - & N.K. & + & - & & - & + & - & - & \\
\hline 39 & 1,612 & 25 & Imb.L. & - & 一 & N.K. & - & - & & - & & - & & $\underset{1929}{\text { W.K. }}$ \\
\hline
\end{tabular}

Table IV represents a group of 21 cases, many of which had abnormal fluids, others gave weak positive M.K.R.'s, and in one case a doubtful positive 
Table III

Congenital Syphilitic Female Defectives

\begin{tabular}{|c|c|c|c|c|c|c|c|c|c|c|c|c|c|c|}
\hline \multirow{2}{*}{ 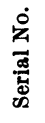 } & \multirow{2}{*}{ 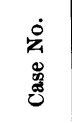 } & \multirow[b]{2}{*}{$\stackrel{8}{4}$} & \multirow{2}{*}{ 营 } & \multirow{2}{*}{ 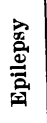 } & \multirow{2}{*}{ 营 } & \multirow{2}{*}{ 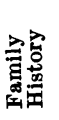 } & \multirow{2}{*}{ 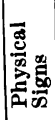 } & \multicolumn{2}{|c|}{ Blood-serum } & \multicolumn{4}{|c|}{ Cerebrospinal Fluid } & \multirow{2}{*}{ Remarks } \\
\hline & & & & & & & & W.R. & M.K.R. & W.R. & Cells & Pandy & Lange & \\
\hline 1 & 19 & 44 & Imb.t. & - & - & N.K. & + & $+30+$ & +++ & - & - & - & - & \\
\hline 2 & 35 & 47 & Imb.L. & + & - & + & + & $+30+$ & +++ & 一 & - & - & - & $\begin{array}{l}\text { Deaf mute } \\
\text { T Choroiditis }\end{array}$ \\
\hline 3 & 43 & 55 & b.L. & + & - & N.K. & + & $+30+$ & ++++ & - & - & - & - & \\
\hline 4 & 216 & 1 & & + & - & + & \pm & & 一 & 一 & 一 & 二 & - & Choroiditis \\
\hline 5 & $\begin{array}{l}360 \\
474\end{array}$ & $\begin{array}{l}27 \\
19\end{array}$ & Imb.M. & $\stackrel{+}{+}$ & $\bar{t}$ & \pm & $\stackrel{+}{+}$ & $+30+$ & -+ & 二 & 二 & 二 & 二 & Choroiditis \\
\hline $\begin{array}{l}0 \\
7\end{array}$ & 573 & 58 & Imb.L. & I & I & N.K. & 工 & $+\overline{30}+$ & + & - & - & - & 二 & Microcephalic \\
\hline 8 & 608 & 30 & F.M. & + & - & + & - & $+30+$ & ++++ & - & - & - & - & Choroiditis \\
\hline 9 & 611 & 73 & Imb.H. & - & - & N.K. & + & $+30+$ & ++++ & - & - & - & - & \\
\hline 10 & 610 & 6 & .H. & - & - & N.K. & + & $+30+$ & ++++ & - & - & - & - & Choroiditis \\
\hline 11 & 614 & 41 & I & - & - & N.K. & \pm & $+30+$ & ++++ & - & - & - & 一 & \\
\hline 12 & 745 & 34 & Imb.L. & - & - & N.K. & \pm & - & ++++ & - & - & - & - & \\
\hline & 756 & 30 & & + & - & + & \pm & $+30+$ & ++++ & - & - & - & - & Hydroce- \\
\hline 14 & 765 & 1 & b.L. & + & - & N.K. & $\overline{+}$ & - & ++++ & - & - & - & - & [phalic \\
\hline 15 & 774 & 19 & F.M. & - & - & N.K. & + & $\overline{a n}$ & +++ & - & - & - & 一 & Blind \\
\hline 16 & 783 & 29 & Imb.M. & + & + & + & + & $+30+$ & ++++ & 一 & - & - & - & Choroiditis \\
\hline $17>-2$ & 791 & 18 & L. & - & 一 & N.K. & + & $+30+$ & ++++ & - & - & - & - & \\
\hline 18 & 88 & 4 & I & - & - & N.K. & \pm & +15 & +++ & 一 & - & - & - & \\
\hline 18 & 896 & 44 & . & - & - & N.K. & $\bar{T}$ & $+30+$ & ++++ & - & - & 一 & - & \\
\hline 20 & 917 & 26 & t. & - & - & N.K. & \pm & - & ++ & - & - & - & - & \\
\hline $91>$ & 95 & 29 & & - & - & N.K. & $\mp$ & $+30+$ & ++++ & - & 一 & 一 & - & Blind \\
\hline 2 & 97 & 2 & & + & - & N.K. & \pm & - & +++ & - & 一 & - & - & \\
\hline 23 & 994 & 28 & Imb.H. & + & - & + & + & $+30+$ & ++++ & 一 & - & - & 一 & \\
\hline 24 & 1,050 & 36 & Imb.M. & - & - & N.K. & \pm & $+30+$ & ++++ & - & 一 & 一 & - & \\
\hline 25 & 1,923 & 58 & Imb.M. & 一 & 一 & N.K. & $\bar{T}$ & - & + & - & - & - & 一 & \\
\hline 26 & 1,994 & 34 & Imb.M. & - & - & N.K. & + & ++ & N.D. & N.D. & N.D. & N.D. & N.D. & $\left\{\begin{array}{l}\text { Banti's } \\
\text { Bant }\end{array}\right.$ \\
\hline 27 & 41 & 49 & H. & - & - & N.K. & + & - & - & + & - & - & 2222110000 & \\
\hline 28 & 116 & 17 & & + & + & N.K. & \pm & $+30+$ & ++++ & $+30+$ & $+t$ & + & 4433210000 & \\
\hline 28 & $\begin{array}{l}135 \\
248\end{array}$ & $\begin{array}{l}29 \\
45\end{array}$ & F.M. & 二 & - & N.K. & \pm & $\begin{array}{l}+30 \\
+30\end{array}$ & $+t \bar{t}+$ & $+3+$ & + & $\bar{t}$ & 000 & \\
\hline $\begin{array}{l}30 \\
31\end{array}$ & $\begin{array}{l}248 \\
569\end{array}$ & $\begin{array}{l}45 \\
52\end{array}$ & In & 二 & 二 & $\begin{array}{l}\text { N.K. } \\
\text { N.K. }\end{array}$ & $\begin{array}{l}+ \\
+\end{array}$ & $\begin{array}{l}+30 \\
+30\end{array}$ & 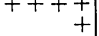 & +3 & \pm & + & 0001221000 & \\
\hline 3 & 600 & 65 & & - & - & N.K. & + & $+30+$ & +++ & $\overline{0}$ & + & + & & Choroiditis \\
\hline 33 & 613 & 45 & Imb.H. & - & - & N.K. & + & $+30+$ & ++++ & $+30+$ & ++ & ++ & 5555443210 & \\
\hline 34 & 1,351 & 30 & Imb.H. & - & - & + & + & 一 & - & +6 & - & - & - & Choroiditis \\
\hline 35 & 82 & 17 & Imb.L. & - & - & - & + & - & - & - & - & + & 2221110000 & $\begin{array}{l}\text { Chorolditis } \\
\text { Deaf mute }\end{array}$ \\
\hline 36 & 350 & 48 & Imb.M. & + & - & - & + & - & - & - & - & + & - & \\
\hline 3 & 801 & 23 & & - & - & N.K. & + & - & 一 & - & + & t & 5554321000 & Mongolian \\
\hline $\begin{array}{l}38 \\
39\end{array}$ & $\begin{array}{l}619 \\
620\end{array}$ & $\begin{array}{l}46 \\
21\end{array}$ & & $\bar{t}$ & + & N.K. & \pm & 二 & - & - & - & - & 二 & \\
\hline 08 & 020 & 21 & Idiot & + & $\ldots$ & N.K. & + & - & & - & - & & - & \\
\hline
\end{tabular}

Wassermann reaction of the blood-serum. It is possible that some of these cases may be of syphilitic origin, but on account of lack of confirmatory evidence they have been classed as non-syphilitic. This leaves 75 cases of congenital syphilis, to which must be added three serologically negative cases, two (nos. 619 and 620) with undoubted clinical signs of congenital syphilis, and one (no. 1,612) with previous positive Wassermann reaction of the blood serum, making 78 in all.

\section{INGIDENGE OF GONGENITAL SYPHILIS}

Of the 78 cases of congenital syphilis the Wassermann reaction was positive in 43 , or 55.1 per cent., and the M.K.R. was positive in 63 , or 80.8 per cent. The latter test is, therefore, the more sensitive one. In the special 


\section{TABLE IV}

\section{Abnormal Serological Reactions in Non-syphilitic Defectives}

\begin{tabular}{|c|c|c|c|c|c|c|c|c|c|c|c|c|c|c|c|}
\hline \multirow[b]{2}{*}{ 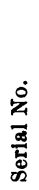 } & \multirow[b]{2}{*}{ 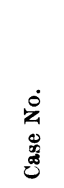 } & \multirow[b]{2}{*}{$\underset{\widetilde{\mathscr{S}}}{\stackrel{x}{J}}$} & \multirow[b]{2}{*}{$\stackrel{8}{4}$} & \multirow[b]{2}{*}{ 营 } & \multirow[b]{2}{*}{ 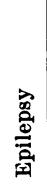 } & \multirow[b]{2}{*}{ 吕 } & \multirow[b]{2}{*}{ 害总 } & \multirow[b]{2}{*}{ 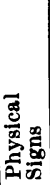 } & \multicolumn{2}{|c|}{$\begin{array}{l}\text { Blood- } \\
\text { serum }\end{array}$} & \multicolumn{4}{|c|}{ Cerebrospinal Fluid } & \multirow{2}{*}{ Remarks } \\
\hline & & & & & & & & & بُ & نَّد & نُ & $\stackrel{\infty}{\overline{0}}$ & 藹 & 总 & \\
\hline 1 & 31 & Male & 26 & Imb.L. & - & - & $\mathrm{K}$ & 一 & + & - & - & - & - & - & \\
\hline 2 & 75 & Mate & 43 & Imb.M. & - & - & N.K. & 二 & \pm & - & - & + & + & 0012321000 & \\
\hline 3 & 137 &, & 44 & Imb.M. & - & - & N.K. & - & 一 & - & 一 & + & + & - & \\
\hline 4 & 169 & ,", & 26 & Imb.H. & - & - & N.K. & - & - & - & - & + & - & - & \\
\hline 5 & 504 & , & 19 & Imb.M. & - & - & N.K. & \pm & - & + & - & 一 & 一 & - & \\
\hline 6 & 1,168 & ," & 20 & Imb.L. & + & + & N.K. & $二$ & - & - & - & - & + & & Quadriplegic \\
\hline 7 & 1,328 & ," & 28 & Imb.L. & + & - & N.K. & - & 一 & - & - & 一 & + & 1122211000 & \\
\hline 8 & 1,334 & ," & 23 & Imb.L. & + & - & N.K. & 一 & 一 & - & - & + & + & 一 & \\
\hline 9 & 1,358 & ", & 29 & Imb.L. & + & + & N.K. & \pm & - & - & - & - & + & - & Diplegic \\
\hline 10 & 1,397 & ", & 39 & Imb.M. & - & - & N.K. & \pm & - & + & - & 一 & - & & \\
\hline 11 & 1,476 & ," & 26 & $\operatorname{Imb} \mathbf{M}$. & - & - & N.K. & \pm & - & - & - & - & ++ & 0000112321 & \\
\hline 12 & 1,519 & ", & 20 & Imb.H. & + & - & N.K. & \pm & 一 & $\bar{t}$ & 二 & + & + & 一 & \\
\hline 13 & 1,525 & ," & 54 & Imb.L. & - & - & N.K. & 二 & - & + & - & - & 二 & 一 & \\
\hline 14 & 1,584 & ", & 35 & Imb.M. & - & - & N.K. & $\overline{1}$ & 二 & $\bar{t}$ & 二 & $+t$ & 二 & 二 & \\
\hline $\begin{array}{l}10 \\
16\end{array}$ & $\begin{array}{r}1,841 \\
219\end{array}$ & Female & 36 & Imb.I. & 二 & 二 & N.K. & \pm & 二 & \pm & 二 & 二 & + & 二 & \\
\hline 17 & 233 & ," & 17 & Imb.L. & - & - & N.K. & 一 & - & - & - & ++ & - & - & \\
\hline 18 & 697 & ", & 17 & Idiot & + & - & - & - & - & - & - & - & ++++ & 0001122334 & Epiloia \\
\hline $\begin{array}{l}19 \\
20\end{array}$ & $\begin{array}{r}699 \\
\end{array}$ & , & 40 & Imb.L. & - & - & N.K. & - & - & $\bar{t}$ & - & $=$ & +++ & 0001122321 & \\
\hline 20 & $\begin{array}{l}1,915 \\
1,922\end{array}$ & ,", & $\begin{array}{l}50 \\
70\end{array}$ & Imb.H. & 二 & 二 & N.K. & $\overline{ \pm}$ & 二 & + & 二 & 二 & 二 & 二 & . \\
\hline & & & & & & & & & & & & & & & \\
\hline
\end{tabular}

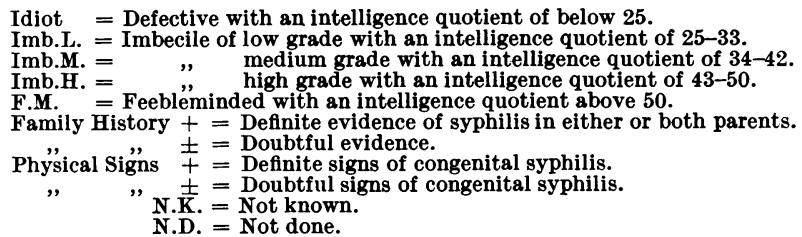

group of 402 children the reverse was the case. Of the total 1,598 cases, excluding acquired syphilis, the incidence of positive Wassermann reactions works out at $2 \cdot 7$ per cent., that of positive M.K.R.'s at 3.9 per cent., and the total incidence of congenital syphilis at 4.9 per cent.

The incidence of positive Wassermann reactions in the group of 402 children was $\mathbf{6 \cdot 7}$ per cent., and the total incidence of congenital syphilis $\mathbf{9 \cdot 2}$ per cent. The lower rate in adults reflects the tendency for the Wassermann and parallel tests to fade with advancing age. One must, therefore, suspect that there are many adult congenital syphilitics giving negative serological reactions. The task of identifying such cases is made extremely difficult by the lack of clinical signs, and by increased difficulty in getting personal and family histories.

\section{RELATIVE INGIDENGE OF GERTAIN GRADES AND DEFEGTS}

An analysis of the various grades of mental defect is given in Table $V$. 
TABLE V

Relative Incidence of Grades

\begin{tabular}{|c|c|c|c|c|c|c|}
\hline & & \multicolumn{2}{|c|}{$\begin{array}{c}\text { Free from congenital } \\
\text { syphilis }\end{array}$} & \multicolumn{2}{|c|}{ Congenital syphilitics } & \multirow{2}{*}{$\begin{array}{c}\text { Percentage } \\
\text { incidence of } \\
\text { congenital } \\
\text { syphilis in } \\
\text { total number } \\
\text { of cases }\end{array}$} \\
\hline & & Number & Per cent. & Number & Per cent. & \\
\hline $\begin{array}{l}\text { Idiot } \\
\text { Imbecile (low grade) } \\
\Rightarrow \quad \text { (medium grade) } \\
\text { Feebleminded grade) } \\
\text { Fe }\end{array}$ & . & $\begin{array}{l}135 \\
560 \\
392 \\
151 \\
282\end{array}$ & $\begin{array}{r}\mathbf{8 . 9} \\
\mathbf{3 6 \cdot 8} \\
25 \cdot 8 \\
9 \cdot 9 \\
18 \cdot 6\end{array}$ & $\begin{array}{r}\mathbf{3} \\
\mathbf{3 1} \\
\mathbf{2 3} \\
\mathbf{1 0} \\
\mathbf{1 1}\end{array}$ & $\begin{array}{r}\mathbf{3} \cdot 9 \\
\mathbf{3 9} \cdot 7 \\
29 \cdot 4 \\
12 \cdot 9 \\
14 \cdot 1\end{array}$ & $\begin{array}{l}2 \cdot 2 \\
5 \cdot 2 \\
5 \cdot 5 \\
6 \cdot 2 \\
3 \cdot 4\end{array}$ \\
\hline Totals . & . & 1,520 & $100 \cdot 0$ & 78 & $100 \cdot 0$ & \\
\hline
\end{tabular}

The imbecile group has the highest incidence of congenital syphilis, the idiot group the lowest, the feebleminded group occupying a middle position. It may be thought that factors such as epilepsy and paralysis would affect the results ; that this is not so is shown by the removal of such cases. There were 1,025 defectives composed of 56 idiots, 752 imbeciles and 217 feebleminded, all free from paralysis and epilepsy. Among the 56 idiots there were no cases of congenital syphilis, the imbeciles had 40 or an incidence of 5.3 per cent., and the feebleminded seven or 2.7 per cent., the relative incidence thus remaining unaltered. It is of interest to note that the same state of affairs prevailed amongst the group of $\mathbf{4 0 2}$ children, though the numbers were too few to draw any conclusions.

Woodall ${ }^{22}$ found precisely the same relation to exist amongst the three grades. After excluding cases of hydrocephalus, microcephalus, paralysis, cretinism, and mongolism, he found the following :-

\begin{tabular}{|c|c|c|c|c|c|c|}
\hline \multicolumn{2}{|c|}{ Moron (feebleminded) } & & & $\begin{array}{c}\text { Number of congenital } \\
\text { syphilitics }\end{array}$ & \multirow{2}{*}{$\begin{array}{c}\text { Total number } \\
\mathbf{5 3 7}\end{array}$} & \multirow{2}{*}{$\begin{array}{c}\text { Per cent. } \\
6.5\end{array}$} \\
\hline \multicolumn{2}{|c|}{ Moron (feebleminded) } & $\bullet$ & - & 35 & & \\
\hline Imbecile . & . & - & - & 31 & 347 & $8 \cdot 9$ \\
\hline Idiot & . & • & - & 12 & 216 & $5 \cdot 6$ \\
\hline
\end{tabular}

Bronfenbrenner ${ }^{1}$ and Dayton ${ }^{3}$ have shown that the incidence of positive Wassermann reactions tends to be lower in the lower grades of mental defect. The former thinks that this is due to a 'degenerative phase of syphilis' affecting idiots to a greater extent than imbeciles or feebleminded, such cases giving a negative Wassermann reaction, and therefore tending to lower the positive incidence in the lower grades of mental defect. This conception has been termed the "intelligence quotient (I.Q.) gradient of the Wassermann reaction in the mental defective,' meaning that the higher the I.Q. the greater the incidence of positive Wassermann reactions, when large numbers of mental defectives of approximately the same age are examined. 
It would seem probable that one of the chief factors influencing the rate of congenital syphilis among the grades in both our group of children and adults is the I.Q. gradient, and that there is a drop in this factor just above the imbecile level.

Congenital syphilis is known occasionally to cause paralysis and epilepsy. A higher rate of congenital syphilis is, therefore, to be expected in the crippleepileptic class of mental defect. This is shown to be the case in Table VI, the uncomplicated group having the lowest incidence.

TABLE VI

Relative Incidence of Certain Defects

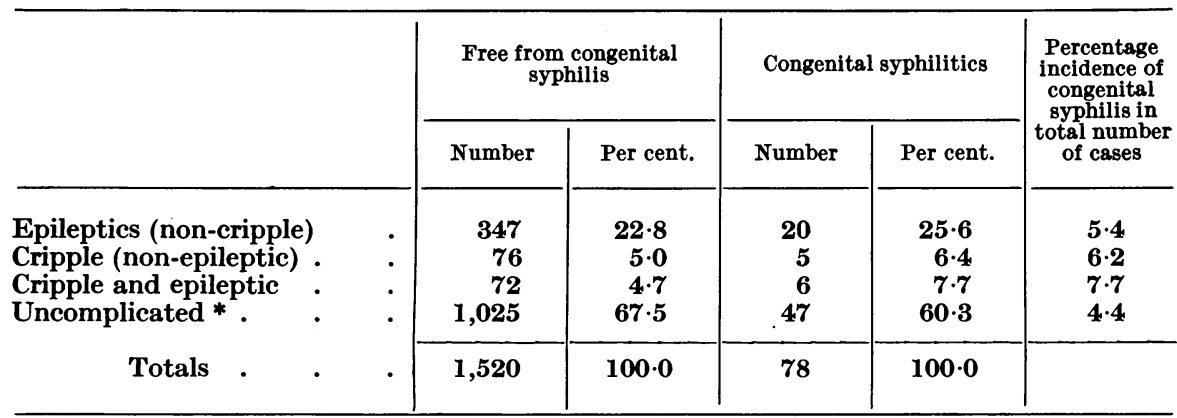

* Not cripple or epileptic.

The incidence of congenital syphilis in certain mental defective types and diseases associated with mental deficiency is given in Table VII.

\section{TABLE VII}

Relation of Congenital Syphilis to Certain Physical Types and Diseases Associated with Mental Deficiency

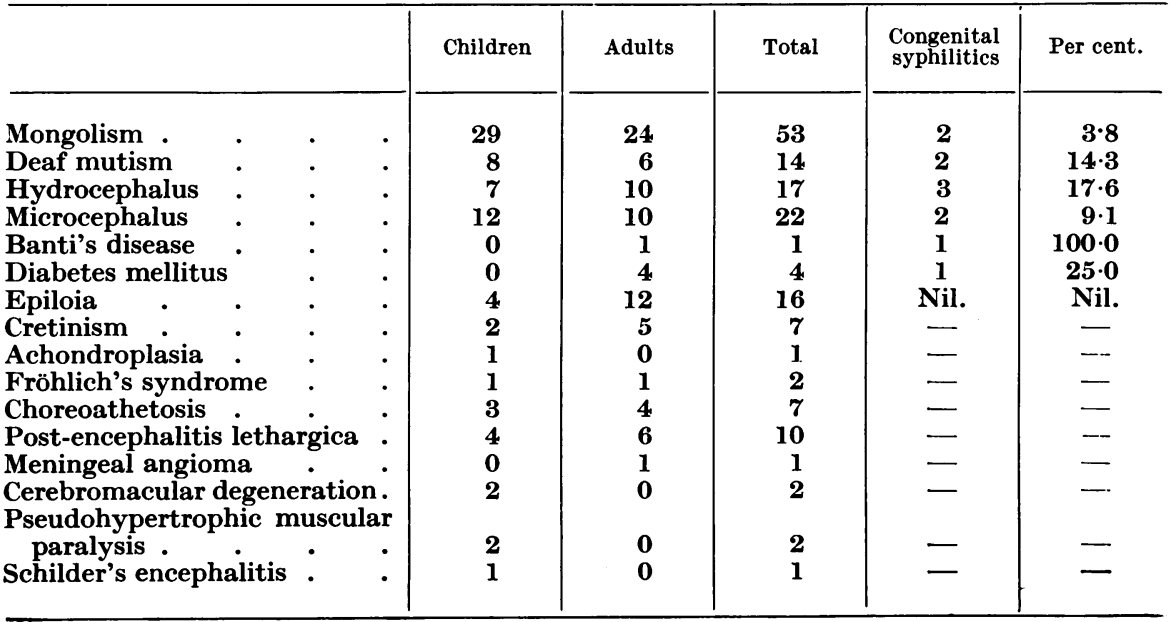


The numbers are rather small, but the low incidence (3.8 per cent.) of congenital syphilis among mongols should be noted, as it has been suggested that there is a direct causal relationship between the two conditions. For example, Stevens ${ }^{19}$ in 1916 found the Wassermann reaction positive in the blood-serum of six out of 18 mongolian idiots, the Wassermann reaction positive in the cerebrospinal fluid in two out of 18, and the gold chloride reaction present in 100 per cent. of the cases. He was of opinion that the serological tests demonstrated beyond question that the condition of mongolism was a result of syphilis, though he thought it probable that the latter acted primarily on some of the endocrine glands, possibly the pituitary body. Riddel and Stewart ${ }^{16}$ have since confirmed Stevens' findings with regard to the property of the spinal fluid of mongols to precipitate solutions of colloidal gold in the luetic zone. They examined the fluid of 55 mongols and all except one gave a luetic curve. The Wassermann reaction was, however, negative in all the fluids, and the cells and globulin all normal; only one out of 55 gave a positive Wassermann reaction in the blood-serum. There were 53 mongol defectives (children included) in our series, all of whom had both blood and cerebrospinal fluid examined. The Wassermann reaction was positive in only one case in the blood-serum, and negative in all the fluids ; in $\mathbf{5 2}$ cases the fluid failed to give any sort of curve with the colloidal gold test (the exception being no. 801), and there was no increase of globulin or cells in these specimens. It therefore appears that syphilis had little to do with the causation of mongolism in our 53 cases.

Banti's disease must be rare amongst mental defectives. Its association with syphilis has been noted by various authors, including Osler. ${ }^{12}$ One such case occurred in our series (no. 1,994) of congenital syphilis, which went to a fatal termination, being fully reported upon [Paddle ${ }^{14}$ ].

Rolleston ${ }^{17}$ in 1921 referred to the importance of endocrine infections in congenital syphilis. He thought 'it would be remarkable if the ductless glands escaped syphilization.' There was one congenital syphilitic in four cases of diabetes mellitus who after treatment with neoarsenobensol was able to dispense with daily injections of insulin. Table VII also shows that such conditions as cretinism, choreoathetosis and post-encephalitis lethargica appear to be unconnected with congenital syphilis.

A complete physical examination, including retinoscopy, was made of all the 78 cases of congenital syphilis, the results being given in Table VIII. One notes the comparative rarity of Hutchinson's and Moon's teeth. 52.6 per cent. of cases had other dental deformities such as described by Fournier, ${ }^{5}$ but these defects are not considered by themselves to be diagnostic of congenital syphilis, as they are often met with in mental defectives apart from syphilis.

Bony lesions are fairly common in congenital syphilis. It is not, therefore, surprising to find that $\mathbf{4 7 \cdot 4}$ per cent. of cases showed abnormal carrying 
TABLE VIII

Signs Associated with Congenital Syphilis in 78 Cases

\begin{tabular}{|c|c|c|c|c|c|c|c|c|c|}
\hline & & & & No. & $\begin{array}{c}\text { Per } \\
\text { cent. }\end{array}$ & & & No. & $\begin{array}{c}\text { Per } \\
\text { cent. }\end{array}$ \\
\hline \multicolumn{4}{|l|}{ Infa } & 7 & $8 \cdot 8$ & Alopecia . & • & 4 & $5 \cdot 1$ \\
\hline Stunted growt & & . & & 12 & $15 \cdot 4$ & Pallor & . & 12 & $15 \cdot 4$ \\
\hline Quadriplegia & - & - & & 1 & $1 \cdot 3$ & Dactylitis. & . & 5 & $6 \cdot 4$ \\
\hline Diplegia . & - & - & & $\mathbf{1}$ & $1 \cdot 3$ & Onychia . & . & 5 & $6 \cdot 4$ \\
\hline Monoplegia & . & . & & 2 & $\mathbf{2 \cdot 6}$ & Scars of old ulcers & . & 18 & $\mathbf{2 3 \cdot 6}$ \\
\hline Hemiplegia & . & . & & 6 & 7.77 & Nodes on bones & . & 12 & $15 \cdot 4$ \\
\hline Strabismus (in & ernal) & & & 3 & $\mathbf{3} \cdot \mathbf{8}$ & Chronic periostitis of & f tibia. & 10 & $12 \cdot 8$ \\
\hline , & ternal) & & & 1 & $1 \cdot 3$ &, of & femur. & 1 & $\mathbf{1} \cdot \mathbf{3}$ \\
\hline Iridoplegia & - & - & & 18 & $\mathbf{2 3} \cdot \mathbf{1}$ & Curved tibia & . & 4 & $5 \cdot 1$ \\
\hline Cataract . & - & - & & $\mathbf{2}$ & $2 \cdot 6$ & Lax ligaments of joir & ints & 3 & $\mathbf{3} \cdot \overline{8}$ \\
\hline Iritis & 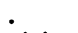 & - & & 12 & $15 \cdot 4$ & Coxa vara & - & 1 & $\mathbf{1} \cdot \mathbf{3}$ \\
\hline Interstitial keI & atitis & . & & 18 & $\mathbf{2 3} \cdot 6$ & Abnormal carrying & angle- & & \\
\hline Choroiditis (di & semins & ated) & & 10 & $12 \cdot 8$ & At elbows . & . & 37 & $47 \cdot 4$ \\
\hline (di & fuse) & - & & 1 & $1 \cdot 3$ & At wrist & $\cdot$ & 3 & $3 \cdot 8$ \\
\hline Atrophied eye & & - & & 2 & $\mathbf{2} \cdot \mathbf{6}$ & Scaphoid scapula & . & 1 & $\mathbf{1} \cdot \mathbf{3}$ \\
\hline Facies syphilit & & . & & 10 & $12 \cdot 8$ & Absent ziphoid apper & ndix & 4 & $5 \cdot 1$ \\
\hline Skull asymme & rical & - & & 9 & $11 \cdot 5$ & General glandular ex & nlarge- & & \\
\hline Sunken bridge & of nos & & & 4 & $5 \cdot 1$ & ment & . & 2 & $2 \cdot 6$ \\
\hline Frontal bossin & & . & & 27 & $34 \cdot 6$ & Splenic enlargement & . & 2 & $2 \cdot 6$ \\
\hline Rhagades. & & . & & 11 & $14 \cdot 1$ & Liver enlargement & . & 2 & $\mathbf{2 \cdot 6}$ \\
\hline Prominent lip & & . & & 27 & $34 \cdot 6$ & Thyroid enlargement & it (sym- & & \\
\hline Scarring of pal & ate & . & & 4 & $5 \cdot 1$ & metrical) & . & 3 & $\mathbf{3 \cdot 8}$ \\
\hline Teeth : Hutch & nson's & & & 4 & $5 \cdot 1$ & Cirrhosis of liver & - & 1 & $\mathbf{1} \cdot \mathbf{3}$ \\
\hline Moon' & & . & & $\mathbf{2}$ & $\mathbf{2} \cdot 6$ & Birth palsy & & 1 & $\mathbf{1} \cdot \mathbf{3}$ \\
\hline other & efects & & & 41 & $52 \cdot 6$ & Unilateral synovitis & of wrist & & \\
\hline Fissured tongr & & . & & 13 & $16 \cdot 7$ & and ankle & . & 1 & $\mathbf{1} \cdot \mathbf{3}$ \\
\hline Cleft palate & & . & & 1 & $1 \cdot 3$ & Mitral stenosis . & . & 4 & $5 \cdot 1$ \\
\hline Eighth nerve & eafnes & & $\cdot$ & 16 & $20 \cdot 5$ & Undescended testes & . & $\mathbf{3}$ & $7 \cdot 6$ \\
\hline Bilateral dacry & ocystit & & 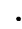 & 6 & $7 \cdot 7$ & & & & (of 39) \\
\hline
\end{tabular}

angles at the elbows. This consisted of a marked outward deviation of the forearm with limited extension in a number of cases.*

In the group of 25 congenital syphilitic boys between the ages of seven and 16, 15 or 60 per cent. had undescended testes; in the group of 39 male adults, only three or $\mathbf{7 \cdot 6}$ per cent. had undescended testes, showing that this condition is really in the large majority of cases one of retarded descent, and not one of permanent arrest in the inguinal canal.

\section{THE GEREBROSPINAL FLUID}

Of 1,598 cases, 1,525 had their cerebrospinal fluid examined for increase in cells and globulin and the Wassermann reaction and Lange's colloidal gold test applied. The results are included in Tables II to IV.

Of these 1,525 cases (excluding 10 of acquired syphilis, four of which had abnormal fluids) the fluid was abnormal in 30, or 2 per cent. This compares with 5.2 per cent. in our previous group of 4.02 children, and 41 per

* I am indebted to Dr. R. M. Stewart for having indicated this sign to me. 
cent. of 48 ' mentally retarded children' reported by Roubinovitch ${ }^{18}$ and his co-workers.

Of the 78 adult cases 'of congenital syphilis the fluid was examined in 76, and of these in 16, or 21 per cent., it was found to be abnormal. In the group of 37 congenital syphilitic children 12, or $32 \cdot 4$ per cent., had abnormal fluids. Among the 78 congenital syphilitics there was only one case of juvenile general paralysis ; his fluid gave a positive Wassermann reaction, a paretic type of curve with the colloidal gold test, and an increase in cells and globulin. Eight other cases gave paretic types of curve, some weak, but none of these cases could on clinical grounds be regarded as juvenile general paralysis.

As already mentioned, the cerebrospinal fluid of 52 out of 53 mongols failed to give any type of curve with the colloidal gold reaction, the exception being a female mongolian imbecile considered on clinical grounds to be a case of congenital syphilis, but with negative Wassermann reaction and Meinicke macro clarification reaction of the blood-serum ; her fluid also gave a negative Wassermann reaction, but there was an increase of cells and globulin and a colloidal gold curve of the paretic type. Of the 21 cases of doubtful origin (Table IV) 14 had abnormal fluids, mostly increases of globulin, six showed increase of cells and five gave colloidal gold reactions, mostly in the middle zone. It is difficult to say what these abnormal fluids represent, as no confirmatory evidence of syphilis was available, and no clinical signs to account for the findings. It is interesting to note that case no. 697, an epiloiac female idiot, has since died, and postmortem a tumour was found beneath the genu of the corpus callosum, bulging into both lateral ventricles, and obliterating by pressure the foramina of Munro, with consequent internal hydrocephalus. This would account for the large increase in protein and the type of colloidal gold curve found in the cerebrospinal fluid when she was alive. Choroiditis appears to be more common in congenital syphilitics with abnormal fluids than in those with normal fluids, the incidence in the former class being 25 per cent. and in the latter 11.7 per cent.

\section{THE INFLUENGE OF AGE AND SEX}

There were 899 males and 699 females, the incidence of congenital syphilis among them being $4 \cdot 3$ and $5 \cdot 6$ per cent. respectively.

If the males and females are separated into age groups (the $\mathbf{4 0 2}$ children being included) and the incidence of congenital syphilis plotted out in the form of a graph, it will be seen that the curves followed by the two sexes are unlike.

The curve for females starts higher than that of the males and is at its lowest between the ages of 31 to 40 . It then rises sharply and is once more higher between the ages of 41 to 50, then falls, to rise again after the age of 60. The male curve, starting lower, falls more gradually, being lowest 
between the ages of 41 to 50, then slowly rises, being higher again after 60 . The initial fall in incidence is mainly due to the fading of the Wassermann and Meinicke reactions with advancing age. The higher incidence among females between the ages of 41 to 50 would suggest the influence of the menopause on these serological tests. Such a view has already been put forward by Nicole ${ }^{11}$ when dealing with acquired syphilis in the insane. He examined 640 females and 989 males, inmates of Winwick Mental Hospital, and came to the conclusion that 'the menopause does affect the serological

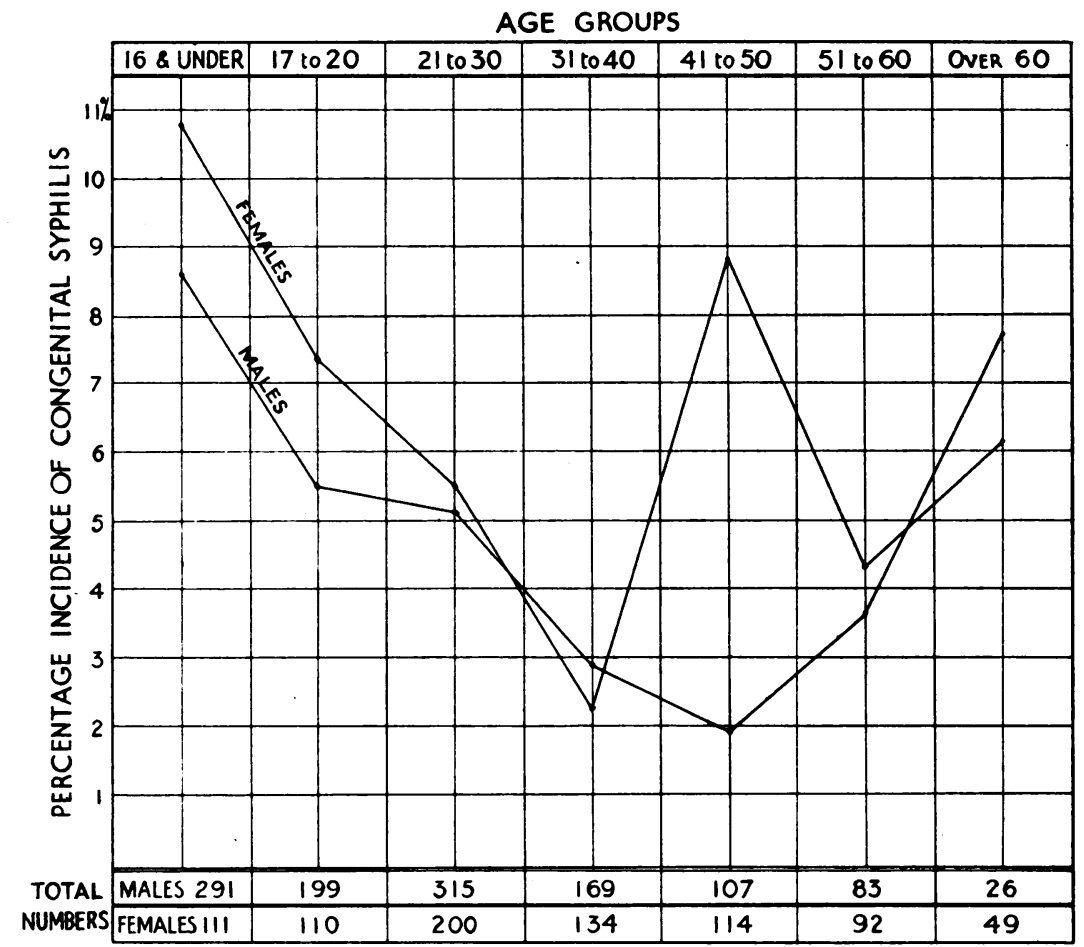

reactions of females,' and 'many of the females examined before 50 give negative reactions, not because they are not syphilitic, but merely because they have not yet reached the menopause.'

\section{SUMMARY}

Fifteen hundred and ninety-eight adult mental defectives of all grades and both sexes had the Wassermann reaction and Meinicke macro clarification reaction done on the blood-serum. Fifteen hundred and twenty-five of these cases had their cerebrospinal fluid examined by the Wassermann reaction, Pandy's test, Lange's colloidal gold test, and for increase of cells. One hundred and six cases gave various abnormal reactions in the blood or cerebrospinal fluid, and 1,492 were serologically negative. Of the 106, 75 
were considered to be congenital syphilitics, and of the 1,492 serologically negative cases, three were deemed on clinical and other grounds to be congenitally syphilitic_-giving a total of 78 cases of hereditary syphilis, or an incidence of 4.9 per cent. The M.K.R. of the blood-serum in adults was more sensitive than the Wassermann reaction.

The incidence of congenital syphilis was higher among imbeciles than idiots or feebleminded, and higher in cripple-epileptics than in uncomplicated cases. There was no evidence to show that mongolism was caused by syphilis. Conditions such as cretinism, choreoathetosis and post-encephalitis lethargica were unconnected with congenital syphilis.

Of 1,525 cases, excluding 10 cases of acquired syphilis with four abnormal fluids, the cerebrospinal fluid was abnormal in 30, or 2 per cent.

In 76 cases of congenital syphilis the fluid was abnormal in 16, or 21 per cent.

The incidence of congenital syphilis was found to fall with advancing age but differed in the sexes. In females it was highest in children and lowest between 31 to 40 , with a sharp rise between 41 to 50 , suggesting a menopausal influence on the serological reactions used. At this age the incidence among the males was at its lowest, but there was a subsequent rise.

My thanks are due to Dr. T. Lindsay, Medical Superintendent of Caterham Mental Hospital, Dr. F. L. Golla, Director of the Central Pathological Laboratory of the London County Mental Hospitals, and Dr. R. M. Stewart, Medical Superintendent of Leavesden Mental Hospital, as well as to my many colleagues, for their helpful advice in this work. I am indebted to Dr. Lindsay for kind permission to publish details of these cases.

\section{REFERENGES}

1 Bronfenbrenner, A. N., 'The Wassermann test in the feebleminded,' Psychiat. Quarterly, 1931, 5, 45.

2 Dayton, N. A., ' Congenital syphilis as a cause of mental deficiency,' Boston Med. Surg. Jour., 1925, 193, 668.

3 Dayton, N. A., 'Degree of mental deficiency resulting from congenital syphilis,' Jour. Amer. Med. Assoc., 1926, 87, 907.

4 Dean, H. R., 'Idiocy and congenital syphilis,' Brit. Jour. Child. Dis., 1912, 9, 385.

5 Fournier, E., Stygmates dystrophiques de l'hérédo-syphilis, 1890, 70.

' Fraser, K., and Watson, H. F., 'The rôle of syphilis in mental deficiency and epilepsy,' Jour. Ment. Sci., 1913, 59, 640.

7 Gordon, J. L., 'The incidence of inherited syphilis in congenital mental deficiency,' Lancet, 1913, 2, 861.

8 KLINE, B. S., Microscopic Slide Precipitation Tests for the Diagnosis and Exclusion of Syphilis, 1932, 8.

- Mann, S. A., and Partner, F., Memorandum on the Wassermann Reaction in Mental Hospitals' Practice, 1931.

10 Motт, Sir F., Proc. Roy. Soc. Med., 1912, 5, 80.

11 Nicole, J. E., 'The age-incidence of seropositive syphilis in females,' Brit. Med. Jour., 1932, 1, 749 . 
12 Osler and McCrae, The Principles and Practice of Medicine, 883.

13 Paddle, K. C. L., 'Congenital syphilis in low-grade mentally defective children,' Brit. Jour. Child. Dis., 1933, 30, 249.

14 Paddle, K. C. L., 'Atrophic coarse cirrhosis of the liver in a congenital syphilitic,' Brit. Med. Jour., 1932, 1.

15 Raviart, G., Breton, M., Petit, G., Gayet and Cannac, 'Réaction de Wassermann et aliénation mentale,' Rev. de méd., 1908, 28, 840.

16 Riddell, D. O., and Stewart, R. M., 'Syphilis as an ætiological factor in Mongolian idiocy,' Jour. Neurol. and Psychopath., 1923, 4, 221.

17 Rolleston, Sir H., Proc. Roy. Soc. Med., 1921, 14, 46.

18 Roubinovitch, J., Baruk and Bariety, 'Le liquide céphalorachidien dans la débilité mentale infantile simple,' L'Encéphale, 1922, 17, 518.

19 Stevens, H. C., 'Mongolian idiocy and syphilis,' Jour. Amer. Med. Assoc., 1916, 66, 1373.

${ }^{20}$ Stewart, R. M., 'The incidence of congenital syphilis in mental deficiency,' Metropolitan Asylums Board Annual Report, 1925-6, 213. 891.

21 Thomson, O., Boas, H., Huort, R., and Leschly, W., Berl. klin. Woch., 1911, 48,

22 Woodall, C. S., 'The incidence of congenital syphilis in an institution for the feebleminded,' Amer. Jour. Psychiat., 1929-30, 9, 1065. 